discordance of strike, and that the limestone lies in a synclinal basin, so that its dip in one place is in the opposite direction to that of the quartzite. From the above considerations the author holds that in these districts there is no proof of the Lower Silurian age of the quartzite and newer series of flaggy gneiss and schist.

3. "On a Boulder of Hornblende-Pikrite near Pen-y-Carnisiog, Anglesey." By Prof. T. G. Bonney, M.A., F.R.S., Sec.G.S.

The boulder described had been originally about a cubic yard in volume, and the fragments lay in a field left of the road from Pen-y-Carnisiog to Bwlyn. The ground-mass consists of hornblende and serpentinous products with a little mica. In this are crystals, often $\frac{2}{3}$ inch long, of brown hornblende with inclosures of altered olivine. The author doubted whether this hornblende is not a paramorph after augite; some of that in the ground-mass is certainly of secondary origin. $H_{\theta}$ compared the rock with a pikrite from the Lleyn peninsula, and two described by Prof. Geikie from Fifeshire. It differs from all these, but has a singular resemblance to a pikrite from Schriesheim (Odenwald), except that it is rather more altered. He called attention to the rock in hopes that some geologists may discover it in situ, as it will be of much value in deciding in what direction the ice has moved over Anglesey.

OOFRESPONDEITCF.

\title{
DISTURBANCES IN THE CHALK OF NORFOLK.
}

Sir,-In the "Annals and Magazine of Natural History," for October, 1880, is an interesting paper by Mr. Jukes-Browne on "The Chalk Bluffs of Trimmingham," wherein, after noting the opinions of various writers concerning their origin and history, he expresses his own conviction that they are outlying rocks or needles formed previously to the deposition of the Pliocene (fluvio-marine) series of the Norfolk coast.

Mr. Jukes-Browne justly compares the disturbances in the chalk at Trimmingham with those at Whitlingham and Swainsthorpe, brought into notice by Mr. J. E. Taylor (Geor. MAG. Vol. II. p. 324; Vol. III. p. 44), and endeavours to support his own view of the date of the Trimmingham disturbance by reference to Mr. Taylor's statement that the Chalk at Whitlingham was disarranged before the formation of the Norwich Crag. In a more recent paper by $\mathrm{Mr}$. Taylor (Geor. MAG. Vol. VI. p. 509) the author, however, attributes the twisting and dragging up of the Chalk and its flint-layers to the agent which formed the Upper or Chalky Boulder-clay. This view I entirely coincide with, and during my Geological Survey-work near Norwich I obtained conclusive evidence that the similar disturbance at Trowse was due to glacial action (Grou. MaG. Dec. II. Vol. VI. p. 380). I differ only from Mr. Taylor in assigning the formation of this Boulder-clay to the direct agency of land-ice, whereas he inclines to the view that the Upper Boulder-clay was formed under glacial-marine conditions, and that the stranding of ice-bergs would cocount for the disturbances of the Chalk. There is much to be said 
on both sides of the question; my object, however, in writing this, was not to discuss the origin of the Chalky Boulder-clay, but to point out that the more remarkable disturbances in the Chalk near Norwich are of glacial origin, and subsequent to the deposition of the Norwich Crag. The section at Litcham, described by Mr. S. V. Wood, jun., tells the same story; and having visited the Bluffs at Trimmingham on many occasions with my colleague, Mr. Clement Reid, I have been led to adopt his explanation that the disturbances of the Chalk there were produced by land-ice.

Fakentham.

HORACE B. WOODWARD.

THE PRE-CAMBRIAN ROCKS OF BRITAIN AND BOHEMJA.

SIR,-In Mr. Marr's valuable paper On the Pre-Devonian Rocks of Bohemia, published in the last number of the Geological Society's Journal, there is one point on which further evidence would seem desirable. I refer to his correlation of the Bohemian gneissic series with the St. David's Dimetian. He describes the Bohemian rocks as "gneiss," "gneissic rock . . . . interspersed with small garnets," "white foliated quartzose rock," "crystalline limestone . ..... strongly foliated, and containing silvery mica." Besides these rocks there is a "band of graphite" and dykes of "black eclogite." Having examined the Dimetian of St. David's from top to bottom, I did not find any one of the varieties named by Mr. Marr. The series is mainly composed of quartzite and granitoid rock, and the existence of foliation has not been proved in either the quartzose or the more felspathic types. I do not deny the Dimetian age of the Bohemian gneiss, but I should hesitate to accept the present evidence as decisive of the point. From Mr. Marr's description, the Pebidian age of étage $A$ appears highly probable, and the discovery is of great interest. The two Pre-Cambrian groups in Bohemia are in their litholngy not unlike the two Anglesey series, of which full descriptions will shortly be communicated to geologists. If the older Anglesey series could be definitely accepted as Dimetian, Mr. Marr's opinion would receive strong confirmation.

C. Callaway.

Welimgton, Salop, Nov. 30, 1880.

ON THE TUSCAN SERPENTINES.

Sir,-The author of the notice of Prof. Pantanelli's paper I Diaspri della Toscana, etc. (GEoL. MAG., 1880, p. 564) inadvertently attributes to me an opinion which I do not bold, when he includes me among those who have recently maintained "that the (Tuscan) serpentines represented true submarine lavas of the Upper Eocene." On the contrary, in my paper (Vol. VI. p. 362) I am at some pains to show that these serpentines are intrusive in the diaspro, etc. The evidence against their being contemporaneous lava flows is strong. It is a remarkable thing that olivine rocks appear very rarely to reach the surface. I have never myself seen a serpentine which was not intrusive. Some pierites, however (e.g. that described by Professor Geikie in his paper on the Volcanic Rocks of the Firth of Forth), and limburgites appear to be lava flows, as may possibly be one or two other olivine rocks.

T. G. BONNEY. 